\title{
Shakespeare's Romeo and Juliet beyond the Boundaries of Page: An Analysis of Baz Luhrmann's Romeo + Juliet and its Balcony Scene
}

\author{
Camila Paula Camilotti \\ Universidade Federal de Santa Catarina, Brazil. \\ Email address: camilapc5@gmail.com
}

\section{Doi:10.5901/ajis.2012.v2n4p53}

\begin{abstract}
:
Whenever a literary work of art crosses the boundaries of page and is transformed in a theatrical play or movie; it goes through a long and complex process of adaptation. What the audience sees and hears on stage or in the big screen is a result of a long journey of work and preparation made by directors and producers according to their conception. Walking in this path, the present paper aims at observing Baz Luhrmann's cinematic version of William Shakespeare's Romeo and Juliet, entitled, Romeo + Juliet and released in 1996. The analysis focuses on how Lurhmann constructed the balcony scene, one of the most famous scenes of the Shakespearian playtext. The analysis shows us that Lurhmann's version is one of the most visually radical screen adaptations of Shakespeare's text and it is capable of impressing the modern spectators and making them aware of the fact that the human artistic capacity is able to cross unimaginable limits of creativity and transform a literary work of art in a great spectacle.
\end{abstract}

Key-words: Romeo and Juliet, Romeo + Juliet, performance, literature

"Good night, good night! Parting is such sweet

Sorrow, /That I shall say good night till it be morrow"

(Romeo and Juliet, 2.2.184-5)

\section{First words}

In his book entitled Theatre at the Crossroads of Culture Patrice Pavis (1992) claims that "for a text to give birth to a performance is no easy matter" (p. 24). To understand Pavis' assumption, it is necessary to acknowledge that a production- and that includes both cinema and theater- goes through a long and complex process of preparation before it reaches the spectators. The elements that compose the performance, such as, text, set design, characters, subtext, and language, are carefully devised by the director, according to his/ her conception. And such conception has to do with that very particular idea that is deep inside the director's mind and insists on being verbalized in a way or another. Sometimes this idea comes from a critical consciousness on the political and historical context of a society and sometimes it comes simply from the desire of exposing, before the eyes and ears of the spectators, an authentic work of art that would enchant them in a way or another.

Jay Halio (1988), in Understanding Shakespeare's plays in performance defines precisely what the director's (or producer's) conception is all about. According to him, it is a "process that involves an increased awareness of what has taken place- and why- in the preparation of the production" (p.5). From Halio's words we may infer that the director's conception is what leads him to prepare the spectacle the way he/she wants, without which there is no performance. It is the starting point for the director's production preparation. It is that idea that is deeply inserted inside his mind and that is capable of transforming everything. Thus, following Halio's notion of adaptation from playtext into performance, I attempt to cross the boundaries of the text written on a page and observe Baz Luhrmann's cinematic version of Shakespeare's Romeo and Juliet, entitled Romeo + Juliet. I am particularly interested in observing how Luhrmann produced the balcony scene, 
one of the most famous scenes of the shakespearian playtext. Since the conception is the starting point for a spectacle to happen, I start this paper by discussing Luhrmann's ${ }^{1}$ apparent intention/conception with his Romeo + Juliet as well as by mentioning some of the most remarkable characteristics of his cinematic version, which is so rich and full of interesting details. Next, I shift to the analysis of the Balcony scene.

\section{Luhrmann's Romeo + Juliet and its peculiarities}

Luhrmann's apparent intention with his cinematic version of Shakespeare's Romeo and Juliet was, as he himself puts it, "to address the notion of Shakespeare on films". And addressing this notion means, for Luhrmann, putting on the big screens a story that would shock the modern spectators as it did in the Elizabethan times, when Shakespeare put it on the stage for the first time. The impact of Romeo and Juliet for the Elizabethan spectators (and also for the modern ones) is not on the death of the couple itself, but on the fact that death came to them when they were still very young. Juliet was about 13 and Romeo, 15. Two children, who would have the world to live in, killing themselves because the love they had for each other was stronger than the capacity of living separately. Moreover, in the midst of this tragic love story, before the very moving end, there are several events that put in the spectator the feeling of anxiety, fear, and desperation, but also of fascination, passion, and delight. Besides the impact, Romeo and Juliet is capable of raising a social, anthropological, and political reflection on the spectators and make them evaluate the values that are so impregnated on the human beings, such as struggle for power, hatred, forgiveness, and love.

Luhrmann, crossing the boundaries of the page and reading what is between the lines in Romeo and Juliet, describes in brief words what the present play is all about (and this first impression on the play will be the guide for his conception later on). According to him, "Shakespeare would have light comedy, high drama, violence, action, popular song. Virtually, all of these wrapped up in one show. So there was not thematic style, it was just anything that grabbed them [the spectators], no matter who they were and we wanted to convert that into a cinematic style" (screen 6). Luhrmann, being aware of the great impact Romeo and Juliet caused on the Elizabethan audience, intended to shock modern spectators with his updating version of the Shakespearian play. As he himself puts it, "we wanted to do a sort of Elizabethan interpretation of Shakespeare [...] we wanted to get back to a kind of violent, direct, passionate, musical, free, energetic, and savage storytelling that it was when this author brought it, for the first time, to the stage". And, if we see the movie and pay attention to the details that surrounded it, we will get to the conclusion that the Irish director really did what he intended to. Broadly speaking, the movie is an intense and shocking twentieth-century version of the Shakespearian playtext and one of the most visually radical screen adaptations of the play.

First of all: the romantic Italian Verona of Shakespeare, where the young lovers live their tragic love story and where Zeffirelli, in 1968 set his version of the Shakespearean play does not exist in Lurhmann's cinematic version of the 1990s. Here, the violent and passionate story happens in a fictitious city, entitled Fair Verona, which mixes Californian and Hispanic styles. To achieve this effect, Luhrmann sets the action in Miami Beach, Florida and in Mexico City, Mexico. In the process of updating Shakespeare's Verona and transforming it in the modern metropolis of Fair Verona, the swords are exchanged by guns and the horses, by futuristic cars. The prologue and epilogue of Shakespeare's playtext, which are extremely important for the overall understanding of the play, are spoken by a journalist on a TV news program. The movie is also full of noises and rumors, capable of putting in evidence its shocking nature.

Interestingly, Luhrmann opted to keep the same language of Shakespeare's text, which, I believe, highlights the paradoxical and shocking nature of the movie. According to Professor Jonathan Bate, who wrote The Genius Shakespeare, this contrast between modern imagery and authentic text, even though it may

${ }^{1}$ The interviews with actors, director, and producers that appear in this article are taken from the extras of Romeo + Juliet's movie DVD, produced by Fox Films in 1996. The reference appears as the number of the screen, in parentheses. 
sound odd to the audience at first, is a positive characteristic in Luhrmann's film. In his words, "one of the greatest achievements of our times is Luhrmann's Romeo + Juliet film, which keeps the authentic text, but updates the setting and makes Shakespeare familiar to a whole new generation". Besides, this odd contrast between modern imagery and authentic text is capable of making the spectators reflect on the fact that social and political problems that occurred in Shakespeare's time also occur in our present times, not mentioning that it is another characteristic in the movie that puts in evidence Lurhmann's intention of giving the modern spectator an Elizabethan interpretation of Shakespeare. As for the thematic concerns, the focus of Luhrmann's Romeo + Juliet is shifted from the eroticism around Romeo and Juliet to the violent world they inhabit. Thus, the movie focuses on the depiction of the corrupt world of the old versus the innocent and pure world of the young. Moreover, the movie is entirely a paradox between the sacred and the profane, the innocence and the perversity, the violence and the peace. The guns and the villains' clothes, which represent the immorality, for instance, are rendered with visible religious images, which represent the sacred.

Another interesting characteristic of Luhrmann's film is the constant water imagery, since a number of important moments involve water. For instance, when Juliet appears for the first time, she has her head under water; Romeo sees her for the first time through a fish tank; when Tybalt is shot by Romeo, he falls into a pound and the rain starts to fall; when Romeo comes to Juliet's room for their wedding night, he is drenched from the pouring rain and when he leaves the next morning, he falls into the pool again. I believe that this frequent presence of water alludes to the purity and transparency of the lovers. In addition to water, the simple way with which Romeo and Juliet dress is another characteristic in the movie that refers to their purity and innocence.

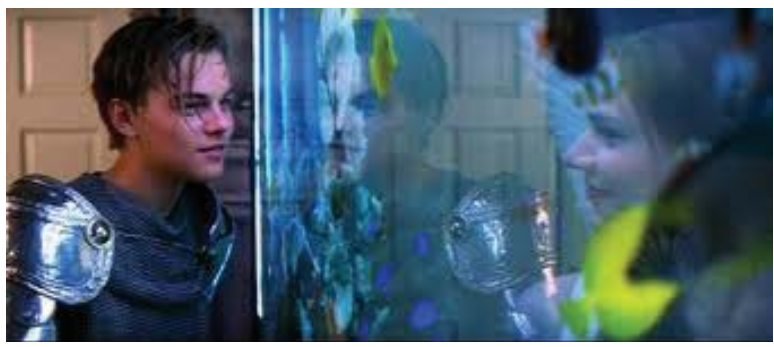

Fig 1: Romeo and Juliet's first meeting through the fish tank.

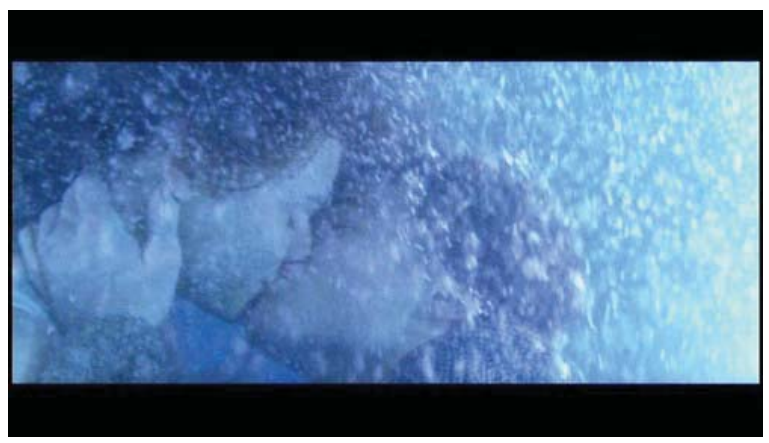

Fig 2: Romeo and Juliet kissing in the swimming pool. 
The characteristics mentioned above were not added to the movie by chance. They are the result of the director's conception and they were possible only after a long process of preparation before the film reached the big screens. Recalling Pavis' quotation in the first paragraph, to make a cinematic version of Shakespeare's Romeo and Juliet was certainly a "difficult birth". A "good" production demands hard work and commitment from the director, actors, and producers. Luhrmann looked at each element that composes the performance separately and carefully.

\subsection{Romeo + Juliet and its balcony scene:}

The first element that the director needed to look at was the text. According to Halio (1988), "the text or script of the play [or movie] is primary, the place where any production and therefore any performance begins" (p. 5). In a performance, the text confronts with other non-verbal language, which Halio calls "stage business" or "visual imagery." Both add information to the playtext and, therefore, there is no need of keeping the entire playtext in a performance, thus, the director cuts or alters the text according to his/her conception. As Halio (1988) explains, "there will always be a certain amount of change made by a theatrical editor, adaptor, or script 'doctor'" (p.4), otherwise the performance would be too long and monotonous.

In relation to the balcony scene, a good amount of lines from the dialogue between the lovers in Shakespeare's playtext were cut, because the visual imagery dispenses these lines. For instance, in the beginning of the corresponding scene in Shakespeare's playtext, the reader imagines that Romeo arrives at Juliet's house and secretly admires her at her window, while she speaks. In Luhrmann's scene, Romeo does not see Juliet. She is inside her room and Romeo is below the window, longing to see his Juliet. When he sees a light coming from the window, he thinks it is his love and is surprised by the sudden appearance of the nurse, who opens the window in front of him. Thus, Romeo's lines that refer to Juliet's description on the window were cut. To be more precise, the lines are the following,

ROM. She speaks, yet she says nothing; what of that?

Her eye discourses, I will answer it.

I am too bold, 'tis not to me she speaks.

Two of the fairest stars in all the heaven,

Having some business, [do] entreat her eyes

To twinkle in their spheres till they return.

What if her eyes were there, they in her head?

The brightness of her cheek would shame those stars,

As daylight doth a lamp; her [eyes] in heaven

Would through the airy region stream so bright

That birds would sing and thing it were not night.

See how she leans her cheek upon her hand!

That I might touch that cheek! (1974, p.12-23)

It is worth mentioning here that the nurse's appearance at the window is a visual interpolation used by Luhrmann, probably to add a certain humor to the scene. In my opinion, it was not a good idea. The balcony scene is supposed to be a romantic moment between the lovers. This humorous moment with the nurse seems to interrupt, at least for a moment, the romantic environment [that is supposed to have in the scene] while Romeo waits for Juliet at the window. A second after the nurse closes the window, Romeo hears Juliet, who comes from the elevator. Then, while Juliet walks from the elevator to the yard, she whispers some words and Romeo secretly hears her and speaks to himself, "She speaks!/ O, Speak again, bright angel!" (26). In the playtext, Romeo's speech continues for some other lines, but in Luhrmann's scene, it stops in line 26. Then, Juliet delivers the famous lines, "O Romeo, Romeo, wherefore art thou Romeo? I Deny thy father and refuse thy name;/ Or if thou wilt not, be but sworn my love,/ And I'll no longer be a Capulet" (33-6). Then, Romeo continues aside, "Shall I hear more, or shall I speak at this?" (36). Then, as soon as Juliet says, "[...] And for thy name, which is no part of thee,/ Take all myself", Romeo approaches 
her and says, "I'll take thee at thy word" (49); Juliet gets startled and they both fall into the swimming pool. Then, there is a beautiful visual interpolation of the lovers looking at each other under the water. Such interpolation seems to allude to the moment they first met, through the fish tank, besides, of course, reinforcing the idea of the transparency of the lovers. Moreover, the soundtrack that plays at this moment is "I'm kissing you", by Des'ree, the same song that was playing when they first met. Due to this visual interpolation, the following dialogue was cut from the playtext:

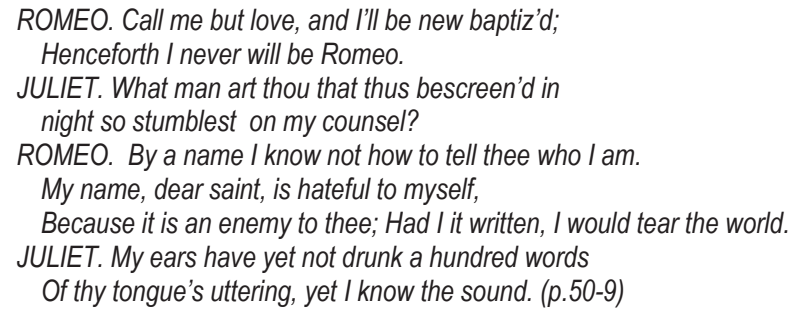

After some time admiring each other under the water, the lovers come back to the edge of the swimming pool and Juliet, still surprised with Romeo's presence, delivers her speech from line 60, "Art thou not Romeo, and a Montague?" Then, the dialogue between the lovers continues and when Romeo delivers line 69, "Therefore thy kinsmen are no stop to me", he is so emotional that he yells and the security guard appears to verify if everything is alright. At this moment, Romeo hides himself under the water until the security guard is gone. As soon as the guard leaves and Romeo returns to the edge of the water, Juliet delivers line 70, "If they do see thee, they will murther thee". Then, there is another visual interpolation of the lovers kissing each other before they start talking again. Thus, the following lines were cut from the playtext, because they were replaced by the lover's kiss:

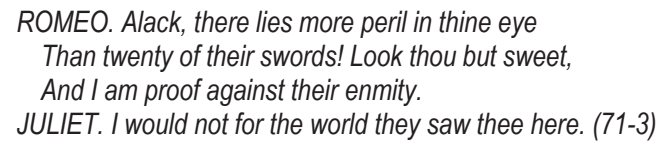

Therefore, Romeo's answer to Juliet is delivered in line 74, "I have night's cloak to hide me from their eyes,I And but thou love me, let them find me here;/ My life were better ended by their hate,I Than death prorogued, wanting of thy love" (74-8). As soon as Romeo delivers his line, "[...] Than death prorogued, wanting of thy love" (78), the lovers kiss for some time. Due to this visual interpolation of the lovers' kiss, six lines, from 79 to 84 , were cut from the playtext. The scene continues with the couple in the swimming pool, exchanging love vows and making declarations of love to each other until Juliet says good night for the first time.

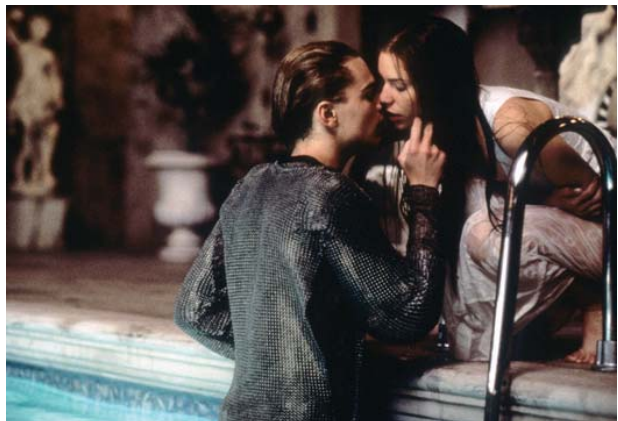

Fig 3: Juliet saying Good night for the first time 
Then, she leaves the swimming pool and Romeo follows her and delivers the famous question: "O, wilt thou leave me so unsatisfied?" (125). Juliet is surprised with Romeo's question, but as soon as he explains her that he means the exchange of their love vows through marriage, Juliet answers, "I gave thee mine before thou didst request it,/ And yet I would it were to give again"(128-9) and runs toward Romeo's direction and they both fall into the swimming pool again. It is possible to say that this visual interpolation shows how transparent and truth the lovers' feeling for each other is, since Juliet falls into the water with Romeo after accepting his proposal. Then, there is another visual imagery of the lovers kissing each other under the water. After some time kissing each other, Juliet interrupts the romantic moment by saying good night for the second time and then she leaves the swimming pool. At this moment, the nurse calls within and, before leaving, Juliet delivers the speech in which she asks Romeo to send her a word through the nurse to arrange their wedding:

\author{
JUL. Three words, dear Romeo, and good night \\ indeed. \\ If that thy bent of love be honorable, \\ Thy purpose of marriage send me word to-morrow, \\ By one that l'll procure to come to thee, \\ Where and what time thou wilt perform the rite, \\ And all my fortunes at thy foot l'll lay, \\ And follow thee my lord throughout the world. (142-48)
}

A second after Juliet finishes her speech, the nurse calls within for the second time and Juliet delivers the following line, "By and by I come-/ But if thou meanest not well,/I do beseech thee" (150). Then, the nurse calls her for the third time and Romeo answers, "so thrive my soul" (153) and Juliet answers: "A thousand times good night! (154) and when Romeo answers: "A thousand times the worse, to want thy light" (155) they kiss and Juliet enters. But, when Romeo is about to leave, Juliet calls him again from her window and gives him her chain with a cross in it. This chain represents the exchange of their love and it accompanies the lovers until their death. Since the cross is a sacred symbol, it alludes to the fact that their love is sacred and endless. Aside from the text, the other important element for the performance is the set design. Nowadays, with technology, it is possible to construct various settings for a performance.

As for cinematic adaptations, things are much easier, due to the possibility of dealing with special effects. Like the text, the director prepares the setting of a performance according to his/her conception. According to Halio (1988), "there are many ways to design sets and costumes for a Shakespeare play [or movie] and no single right way. But some ways may be more appropriate and effective than others, given the audience, the circumstances, and the particular play [or movie]" (p. 22). As already mentioned, Luhrmann chose to construct a modern setting for his version of Romeo and Juliet. The balcony scene happens in the Capulets' yard, in the swimming pool. To agree with the updating setting, The Capulets' mansion is thoroughly modern, with high technology. As soon as Romeo enters the yard, electronic lights are turned on and he gets scared. For this reason, he makes noise and hides himself. The house is surrounded by cameras and the security guards have a special room from where they monitor the mansion. The elevator also plays an important part in the scene, because it brings Juliet down to the yard.

As for the costumes, they are also part of the visual elements and they do not need to be necessarily related to the setting. Some directors, for instance, choose a modern setting for historical costumes and viceversa. In Luhrmann's film, Romeo and Juliet dress in a simple way, usually with light colors, light blue or white. In the costume party, Juliet is dressed in a delicate way, like an angel, and she really looks like an angel. Her dress is white and she carries wings. Romeo is dressed like a knight. Kim Barrett, the costume designer, explains, "I looked into the script mostly and got clues from what they said. Romeo calls Juliet 'bright angel' and they call him a prince. It just seemed to me that, that is what they could be" (screen 3). 


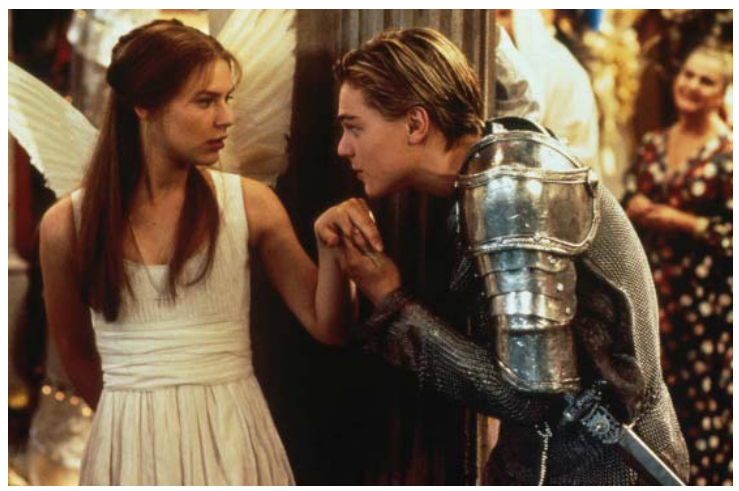

Fig 4: Juliet dressed like and Angel and Romeo like a knight.

As for the other characters in the movie, the Montagues dress in a simple and casual way, with Hawaiian style shirts and plain pants. The Capulets, on the contrary, dress in a "gun fighting" style, with a kind of bullet style vest. Both the Capulets and the Montagues wear ornamental tattoos, but the Capulets wear threatening jewelry as well to reinforce their characteristic as aggressive. According to the reviewer Desson Howe, "Luhrmann turns the Montagues into flower-shirted, Miami Beach-like punks, who sport $9 \mathrm{~mm}$ revolvers rather than swords. The Capulets are street princes in funereal black, also armed to the teeth" (par. 6).The next element to be discussed has to do with character construction, therefore, the actors' performance. According to Halio (1988), "[constructing] a character is perhaps the most difficult problem an actor has to solve in approaching any important role, though even minor roles raise similar questions"(p.31).

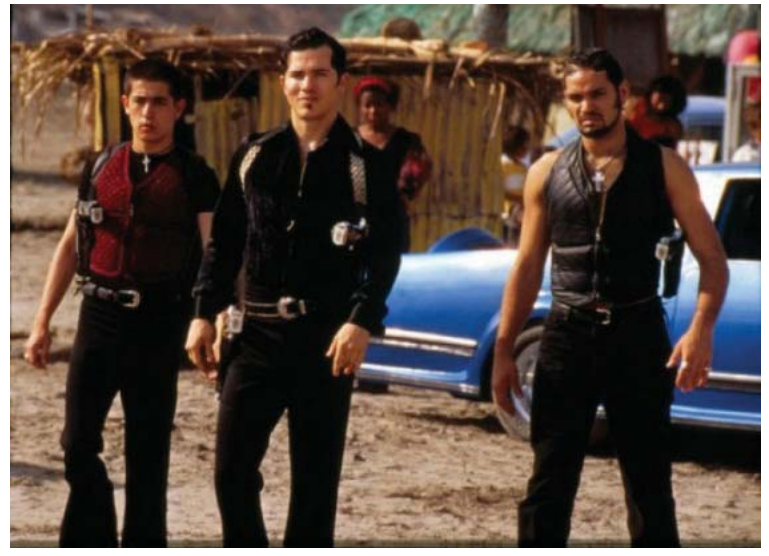

Fig 5: the Montagues' costumes

The actors' challenge lays on the fact that they have to absorb the character completely and sometimes they do not have any idea about how to interpret a given role. For Pavis (1992), the difficulty of constructing a character lays on the fact that the actors have habits, convictions, expectations, and cultural traces that cannot be left behind ( $p .9)$. When they approach a role, they have to be able to "undo" their manners and, therefore, give life to it. Moreover, in the process of character construction, the actors 
have to construct the subtext for their character. Halio (1988) argues that the subtext is important, because "it is directly related both to the script the actor is performing and to the actor's inner creative life--the ability to infuse life into a script or rather breathe life from it" (p. 40).

The process is not over yet. After constructing their own roles, the actors should be able to interact with the other actors in the performance. Halio defines this interaction as "ensemble acting". According to the author (1988), it is "the sort that comes from actors being well rehearsed together as a group, attuned to one another's subleties of interpretation and delivery so that the production appears as a seamless garment" (p.74). Thus, before the performance reaches the spectators, the actors have a long process of preparation with play readings, stage rehearsals, and body preparation. As for Romeo +Juliet, the actors had a long process of preparation and rehearsal before actually shooting the scenes. Leonardo Dicaprio, who interprets Romeo, reveals the difficulty in performing a Shakespearean character. According to him, "Once you really get into the character and you realize how human it is, you sort of get lost" (screen 4). Claire Danes, who interprets Juliet, also reveals that "the death scenes were really hard to face" (screen 6).

As for the balcony scene, it was very hard for the actors to shoot it. The shooting was not working, hence the actors had to record it again one week later. The rehearsals for this scene were in cold water, so the actors' body would keep a light color and would not get red. In addition to the construction of their own characters, the actors should be able to work with the language, or in other words, with the delivery of their speech. It is the actors' job to articulate well the words, with the correct pauses, and the correct emphasis, because, as Halio (1988) explains, "modulation, phrasing, pause- all these aspects of careful and precise articulation help the audience [construct] the language they need to engage their imagination" (p.54). But asides from that, competent delivery of the language enriches the actors' performance and consequently their roles. In relation to the balcony scene, there is not much to say about the language itself, because, as aforementioned, Luhrmann kept the authentic Shakespearean text, but there is something to say about the actors' delivery of this poetic Shakespearean text.

The reviewer Peter Travis praises Dicaprio and Danes for their delivery. According to Travis (2001, p.89):

As Romeo, Dicaprio doesn't round his vowels (tonight becomes tanight) or enunciate in dulcet tones, but when he speaks, you believe him. Whether Romeo is lovesick ("Did my heart love till now?"), violent ("Tempt not a desperate man") or drugged ("A dateless bargain to engrossing death"), Dicaprio lets the Bard's words flow with an ardor that you can't buy in acting class. Claire Danes wisely chooses to emphasize Juliet's melting loveliness and bristling wit. When the lusty Romeo, on their first date, complains of being left unsatisfied with only a kiss, Juliet turns on him. "What satisfaction canst thou have tonight?" she asks. The fire in Danes' eyes is unmistakable: Juliet is interested, but not for now.

Unlike Trevis, the reviewer Roger Elbert criticizes Dicaprio's and Danes' deliveries. According to $\operatorname{him}(1996, \mathrm{p} .5)$ :

Much of the dialogue is shouted unintelligibly, while the rest is recited dutifully, as in a high school production. Leonardo Dicaprio and Claire Danes are talented and appealing young actors, but they're in over their heads here. There is a way to speak Shakespeare's language so that it can be heard and understood, and they have not mastered it.

I agree with Elbert. Dicaprio and Danes did not fit for the roles of this Shakespearean couple, indeed. Dicaprio makes a visible effort to pronounce the Shakespearean text by heart and, therefore, his delivery becomes rather artificial. He gives the impression that he fights with the words all the time. Danes' delivery was better compared to Dicaprio's, but she could not reach the richness of Shakespeare's Juliet as well. 


\section{Final remarks}

On the whole, the balcony scene was efficacious, in spite of the poor performance of the main actors and the nurse's appearance. The way Luhrmann produced the balcony scene was creative. His idea of setting the scene in the swimming pool was excellent, because it was possible to associate the water with the lovers' purity and true feelings. In addition, the constant visual imagery of the couple kissing and admiring each other under the water is beautiful and romantic. As observed, the process of adaptation is not any easy. The director, actors, and producers spend months, perhaps years, working hard in the preparation of each element that composes the performance before it reaches the spectators. Every detail of the spectacle, be it visual, be it textual, tells a lot to the performance as a whole and was carefully chosen by the director. Nothing, absolutely nothing, in a performance happens by chance. Therefore, it is extremely important to have a conception before making an adaptation. Luhrmann's cinematic version of Shakespeare's Romeo and Juliet is an example of a clear conception: Luhrmann wanted to make an Elizabethan interpretation of Shakespeare's Romeo and Juliet for modern spectators. Thus, he kept the authentic language and updated the setting. The result is a radical and shocking version of Shakespeare's play, which caused a great impact on the cinematic world: Some spectators hated it, some loved it, but they all have to agree that Luhrmann does have a conception.

\section{References}

Barrett, Kim. Interview. Interview Gallery. In: Luhrmann, Baz (Director). (1996). Romeo + Juliet. [DVD]. United States: Twentieth Century Fox Films.

Bate, Jonathan. "The Impact." Interview. In: Luhrmann, Baz (Director). (1996). Romeo + Juliet. [DVD]. United States: Twentieth Century Fox Films.

Danes, Claire. Interview. In: Luhrmann, Baz (Director). (1996). Romeo + Juliet. [DVD]. United States: Twentieth Century Fox Films.

Dicaprio, Leonardo. Interview. In: Luhrmann, Baz (Director). (1996). Romeo + Juliet. [DVD]. United States: Twentieth Century Fox Films.

Elbert, Roger. (1996, Nov.01). Romeo \& Juliet. Chicago Suntimes. Retrieved from: <http://rogerebert.suntimes.com/apps/pbcs.dll/article?AID=/19961101/REVIEWS/611010304/1023>

Halio, Jay. (1988). Understanding Shakespeare's Plays in Performance.USA: Scrivenery Press.

Howe, Desson. (1996, Nov.16). This Romeo is bleeding. Washington Post. Retrieved from: <http://www.washingtonpost.com/wp- srv/style/longterm/movies/review97/romeoandjuliethowe.htm>

Luhrmann, Baz. "Why Shakespeare." Interview. In: (1996). Romeo + Juliet. [DVD]. United States: Twentieth Century Fox Films.

Pavis, Patrice. (1992). Theatre at the Crossroads of Culture. London and New York: Routledge,

Luhrmann, Baz (Director). (1996). Romeo + Juliet [DVD]. United States: Twentieth Century Fox Films.

Shakespeare, William. (1974). The Riverside Shakespeare. USA: Haughton Mifflin.

Travis, Peter. (2001, Apr.18). William Shakespeare's Romeo + Juliet. Rolling Stone. Retrieved from: <http://www.rollingstone.com/reviews/movie/5949093/review/5949094/william_shakespeares_romeo__uliet > 
